\title{
Differential expression of related molecules after acute injury of rabbits' anterior cruciate ligament and medial collateral ligament
}

Yu Wen ( $\nabla$ ywen2008cmu@163.com )

China Medical University https://orcid.org/0000-0001-6994-2141

\section{Yin-he Han}

China Medical University

Huining Gu

China Medical University

Mingzheng Zhang

Shengjing Hospital of China Medical University

Bin Li

Shengjing Hospital of China Medical University

\section{Research Article}

Keywords: anterior cruciate ligament, medial collateral ligament, RT-qPCR, Western blot, Matrix Metalloproteinases, collagen,

Posted Date: February 15th, 2021

DOl: https://doi.org/10.21203/rs.3.rs-195002/v1

License: (c) (i) This work is licensed under a Creative Commons Attribution 4.0 International License. Read Full License 


\section{Abstract}

Objective: This study aimed to assay expression of the mRNA and proteins for injuring- and angiogenesis-associated molecules at 3 days, 1 week, 2 weeks, 4 weeks and 6 weeks after anterior cruciate ligament or medial collateral ligament injury in male New Zealand White rabbits.

Methods: Models similar to those of clinical patients were used to establish acute partial injuries of the anterior cruciate ligament and medial collateral ligament at 3 days, 1 week, 2 weeks, 4 weeks and 6 weeks and normal control groups. Molecular biological changes in male rabbits were detected at different time points after anterior cruciate ligament and medial collateral ligament injury by H\&E staining, reverse transcriptase chain reaction and westren blotting.

Results: Marked differences were found in the postinjury changes in gene levels and proteins in the anterior cruciate ligament compared to the medial collateral ligament. There was no increase in mRNA expression of TIMP3, TGF- $\beta$ and PRG4 in the injured anterior cruciate ligament at any time point. However, the levels of these genes tended to increase in the injured medial collateral ligament. In contrast, MMP-13 mRNA levels were significantly increased in the injured anterior cruciate ligament, but not in the medial collateral ligament. Furthermore, vascular endothelial growth factor decreased following injury to both the anterior cruciate ligament and medial collateral ligament, with the difference being a slight decrease in the medial collateral ligament and a significant decrease in the anterior cruciate ligament. Similarly, protein blots showed higher protein expression of type I and type III collagen in the injured medial collateral ligament than in the anterior cruciate ligament.

Conclusion: The results show that there were drastic differences in angiogenesis, collagen and Matrix metalloproteinases after anterior cruciate ligament and medial collateral ligament injury. It can be found that the repair ability of the anterior cruciate ligament and medial collateral ligament after injury may be related to the differences in molecular expression.

\section{Introduction}

The knee is the joint most susceptible to injury during sports activities, and the ligaments in the knee in particular can be frequently damaged[1]. In the United States alone, ligament injuries result in over 100,000 disabilities each year [2]. The two most vulnerable ligaments in the knee are the ACL (Anterior cruciate ligament) and the MCL (Medial collateral ligament). Both clinical and basic experimental studies have shown that these two kinds of ligaments have different healing potential after injuring. The MCL will repair itself after trauma[3], while ACL cannot be repaired endogenously[4]. Therefore, surgical treatment has always been the means of repairing ACL injuries. However, with the development of scientific research, surgical treatment has been found to have many complications and disadvantages, such as postoperative osteoarthritis and secondary injury[5].

The drastic difference in healing capacity between ACL and MCL injuries is still largely unexplained. Earlier studies believe that the differences in endogenous repair after ACL and $M C L$ injury are mainly due 
to different mechanical environments[6]as well as differences in nitric oxide synthesis[7], differences in blood supply[8], and differences in the proliferative potential of fibroblasts[9] and differences in lysyl oxidase (LOX) expression[10]. There is a large body of evidence for differences in blood supply and differences in fibroblast proliferation. Bray RC[11] et al have shown that,after injury, MCL is more abundant in blood vessel volume and blood flow than ACL. Wiig[12] et al found that the expression of collagen genes in ACL fibroblasts was lower compared to MCL.

In recent years, with advances in molecular biology research, it has been found that a severe hypoxic environment is also a factor in the differences in endogenous repair between ACL and MCL after injury, mainly due to the adverse regulation of matrix metalloproteinases expression levels[13]. Some studies have also found that differences in self-healing ability between ACL and MCL are also related to the scaffold that the load cells and ligaments bind[14]. MCL can form scaffold after injury, but ACL cannot form a scaffold. This may be another factor affecting the endogenous repair of ACL injury.

In addition, differences in the proliferation of the two types of ligament stem cells could also explain the differences in repair capacity. Stem cells have a high differentiation capacity and are important for angiogenesis and fibroblast proliferation and differentiation, and play an important role in ligament repair. Zhang J[15] et al studied ACL and MCL ligament stem cells and found that MCL stem cells proliferated faster than ACL stem cells.

During ligament healing, many growth factors play an important role in repair by activating cell migration and matrix synthesis. The effect of growth factors on matrix synthesis is evident in ACL and MCL cells. Transforming Growth Factor- $\beta$ (TGF- $\beta$ ), Epidermal Growth Factor (EGF), Growth and Differentiation Factor 5(GDF-5) and Bone Morphogenetic Protein-7 (BMP-7) stimulate the expression of type I and type III collagen in ligamentous tissue [16-17]. Several studies have found that Nerve Growth Factor(NGF) may promote the synthesis of collagen I[18]. Therefore, studying the differences in growth factors after MCL and $A C L$ injury is an important reference for the endogenous repair and collagen expression in ACL. Moreover, TGF- $\beta$, Vascular Endothelial Growth Factor (VEGF) and NGF are associated with angiogenesis. Angiogenesis is an essential step in the healing process, which helps to repair and reconstruct injured tissues.

After ligament injury, fibroblasts are stimulated by inflammation (cytokines and mechanical microenvironment) to obtain the "proto-myofibroblast" phenotype, and then differentiate into typical myofibroblasts, which are characterized by newly expressing a-Smooth muscle actin (a SMA), which is the dominant actin subtype in vascular smooth muscle cells[19]. PRG4 (proteoglycan4) is a proteoglycan 4 , also known as a lubricant, with many unique biological functions, including lubrication, anti adhesion and as a regulator of cell growth[20]. Both aSMA and PRG4 play an important role in the proliferation of ligament fibroblasts. Collectively, these molecules are important regulators and products of cellular activity in healing tissues.

Matrix metalloproteinases are produced by various connective tissue cells, such as fibroblasts, endothelial cells, osteoblasts, and macrophages[21]. They have functions in tissue remodeling and repair, 
basement membrane degradation, tumor invasion, and neovascularization[22-23]. For example, (matrix metalloproteinases 3)MMP3 and (matrix metalloproteinases 13)MMP13 exhibit catabolic effects on collagen types I, II and III[24]. MMPs are regulated by endogenous tissue inhibitors of metalloproteinases (TIMPs) and urinary plasminogen activator (UPA) converts fibrinogen into fibrin, an active protease involved in fibrinolysis and collagen degradation. Fibrin also degrades certain components of the extracellular matrix and may activate a variety of MMPs[25]. The ratio of MMPs/TIMPs usually determines the degree of extracellular matrix protein degradation and tissue remodeling, so MMPs and TIMPs series play a key role in maintaining the balance between extracellular matrix (ECM) deposition and degradation[26]. Under normal circumstances, there is a relative balance between MMPs and TIMPs in the tissue, which determines the stability of the matrix. The imbalance of MMPs and TIMPs ratio leads to the destruction of tissue structure and function and instability of joint. When the MMPs expression increases, the TIMPs expression decreases, which causes abnormal EMC degradation, leading to differences in tissue repair capabilities. Because both plasmin and MMPs have the function of degrading extracellular matrix to accommodate new blood vessels, uPA can be classified into substances like MMPs. After comparing the expression of different MMPs in MCL and ACL, Zhou et al[2] found that the activity of MMPs in injured ACL was higher than that in MCL. Therefore, it was concluded that many MMPs may be related to the difference in healing potential.

In addition, the difference of collagen composition between the two kinds of ligaments may also affect the self-healing ability. Collagen is the main component of ligaments, accounting for about $75 \%$ of ligament dry weight, of which type I and III collagen account for about $90 \%$ of the total collagen in the body. Type I collagen is responsible for the strength and endurance of ligament, and type III collagen is involved in ligament repair[27]. Collagen has the function of mechanical support, participates in cell attachment, migration, growth, proliferation and differentiation, and plays an important role in maintaining structural stability. Chamberlain et al[28] found that collagen synthesis increased significantly after ligament injury. Chun et al [29] and Murakami Het et al [30]have found that MCL fibroblasts in vitro can synthesize more collagen than ACL fibroblasts, and ACL fibroblasts are more likely to produce nitric oxide to induce apoptosis than MCL fibroblasts. Therefore, it is very important to study the difference of collagen after $A C L$ and $M C L$ injury to study the mechanism of endogenous repair difference between ACL and MCL.

There are relatively few descriptions about gene expression and protein expression of ligament after injury in the literature. The purpose of this study was to compare the the expression of angiogenesisrelated molecules, basement membrane degrading enzymes, inhibitors of angiogenic molecules, mRNA of matrix composition and associated protein molecules after acute ACL and MCL injury. We studied VEGF, TGF- $\beta$ and NGF, three molecules associated with angiogenesis. Two matrix metalloproteinases and their inhibitors, MMP3 and MMP13, as well as TIMP-1 and TIMP-3 and the matrix metalloproteinase activator UPA. It also included aSMA and PRG4, as well as the most abundant type I and type III collagen in ligaments. This study used a model similar to that of clinical patients to examine the molecular biology of the $A C L$ and $M C L$ at different periods of injury, to identify factors affecting endogenous repair of the $A C L$, and to provide a basis for the treatment and repair of ACL injuries. 


\section{Materials And Methods}

\section{Reagents and equipments}

Tissue freezing medium (OCT, SAKURA 4583) was purchased from Sakura Finetek (Torrance, California, USA), the first antibody rabbit polyclonal antibody COL3A1 was purchased from Solarbio (Beijing, China), rabbit monoclonal antibody COL1A1/Collagen was purchased from Beyotime ( Shanghai, China),rabbit polyclonal antibody MMP1 was purchased from Beyotime (Shanghai, China) $\square$ rabbit polyclonal antibody MMP13 was purchased from ABclonal (Wuhan, China) $\square$ rabbit polyclonal antibody MMP3 was purchased from proteintech (Chicago, USA) and mouse monoclonal antibody $\beta$-Actin was purchased from Beyotime (Shanghai, China) $\square$ secondary antibody (goat anti-mouse IgG 1:5000 and goat anti-rabbit IgG1:5000) was purchased from proteintech (Chicago, USA), antibody dilution was purchased from Beyotime (Shanghai, China) $\square$ All primers were purchased from Invitrogen (Carlsbad, California, USA) $\square$ Reverse transcription kit (GoScript ${ }^{\text {TM }}$ Reverse Transcription System) and high-efficiency fluorescence quantification kit (GoTaq ${ }^{\circledR}$ qPCR Master Mix) were purchased from Promega (Madison, Wisconsin, USA) $\square$ The cryostat comes from Leica CM1950 (Solms, Germany), and the real-time PCR system (LightCyclerß96) from Roche (Basel, Switzerland).

\section{Laboratory Animals}

A total of 20 male 3-month-old New Zealand white rabbits weighting between 2.5 and $3 \mathrm{~kg}$ were purchased from the laboratory animal department of China Medical University. Each animal was handled in accordance with the guidelines of Animal Ethics Committee of China Medical University. They were divided into 6 groups of 3 days, 1 week, 2 weeks, 4 weeks, 6 weeks and normal control group, each group with 3 rabbits. Each rabbit was kept in a single cage and placed in the Animal Department of China Medical University, and was kept normally before the experiment.

\section{Surgery}

Eighteen experimental animal rabbits were anesthetized by intravenous injection of barbital sodium $(1 \mathrm{ml} / \mathrm{kg}, 2 \mathrm{ml}$;China medical university China). After the anesthesia took effect, the experimental animals were placed supine on the experimental table the upper limbs were cross-fixed, and then the surgical area was strictly iodophor disinfected, and a disposable sterile towel was placed on the surgical area. Nextlthe rabbits'knee joints were taken on the medial side and made an incision with a longitudinal length of about $1.5 \mathrm{~cm}$. Cut the skin, bluntly separate the subcutaneous tissue and joint capsule, fully expose the $A C L$, flex the knee joint to 90 , pierce the $A C L$ femoral end with a $20 \mathrm{ml}$ needle, and then similarly pierce the proximal third of the femoral end of the MCL, Wash the wound with normal saline, and suture the joint capsule and skin with $4-0$ sutures. Three animals were not treated as a positive control. After the operation, all experimental animals were injected intramuscularly with the anti-infective ceftriaxone sodium for 5 days.

\section{Tissue Samples Collection}


The surgical animals were carefully raised, and the animals were euthanized by injecting air into the ear vein at $3 d, 1 w, 2 w, 4 w$ and $6 w$ of the injury, and then the entire MCL and ACL of each injured leg were cut off and stored at $-80^{\circ} \mathrm{C}$.

\section{Rna Extraction And Quantification}

According to the TRIZON method, total RNA was extracted from all tissue samples. Briefly, add $1 \mathrm{ml} / 100 \mathrm{mg}$ of the sample to trizon reagent, grind the tissue with a nucleic acid extractor to crush, add chloroform, then add 400-500ul of isopropanol, mix and centrifuge, and finally wash the RNA with 75\% ethanol and dry at room temperature,then the Total RNA could be obtained, and it could be frozen at $-80^{\circ} \mathrm{C}$ or in subsequent experiments.

\section{Determination Of Gene Levels}

For each sample, $500 \mathrm{ng}$ total RNA was reverse transcribed using GoScript ${ }^{\mathrm{TM}}$ Reverse Transcription System Kit (Promega). First, pre-denatured at $70^{\circ} \mathrm{C}$ for 5 minutes, then annealed at $25^{\circ} \mathrm{C}$ for 5 minutes, followed by extension at $42{ }^{\circ} \mathrm{C}$ for 60 minutes and at $70^{\circ} \mathrm{C}$ for 15 minutes to obtain CDNA. For the cDNA of each sample, use GoTaq ${ }^{\circledR}$ qPCR Master Mix kit to amplify 1 ul of CDNA in a two-step method. The required gene primers are shown in Table 1 below. The first is a cycle of pre-denaturation, after $120 \mathrm{~s}$ of pre-denaturation at $95^{\circ} \mathrm{C}$, followed by 40 cycles of amplification, the first step is $95^{\circ} \mathrm{C}$ amplification for 15 seconds, and the second step is $60^{\circ} \mathrm{C}$ amplification for 60 seconds. 
Table 1

Primers for quantitative real-time PCR analysis

\begin{tabular}{|c|c|}
\hline Gene & Sequences \\
\hline \multirow[t]{2}{*}{$\beta$-Actin } & Forward:5- 'TGC TTC TAG GCGGACTGT TA-3' \\
\hline & Reverse: 5'-CGTCAC ATGGCATCTCAC GA -3' \\
\hline \multirow[t]{2}{*}{ Collagen I } & Forward: 5'-GATGCGTTCCAGTTCGAGTA - 3' \\
\hline & Reverse: 5'-GGTCTTCCGGTGGTCTTG TA-3' \\
\hline \multirow[t]{2}{*}{ Collagen III } & Forward: 5'-TTATAAACСААССТСТТССТ-3' \\
\hline & Reverse: 5'-TATTATAGC ACC ATT GAG AC-3' \\
\hline \multirow[t]{2}{*}{ TGF- $\beta 1$} & Forward: 5'-CGGCAGCTGTACATTGACTT-3' \\
\hline & Reverse: 5'-AGCGCACGATCATGTTGG AC-3' \\
\hline \multirow[t]{2}{*}{ NGF } & Forward: 5'-TCCACCCAC CCA GTCTTC CA-3' \\
\hline & Reverse: 5'-GCCTTCCTG CTG AGC ACA CA-3' \\
\hline \multirow[t]{2}{*}{ VEGF } & Forward: 5'- GGAGTACCCTGATGAGATCGA-3' \\
\hline & Reverse:5'-CTTTGGTCTGCATTCACATTT GT-3' \\
\hline \multirow[t]{2}{*}{ MMP-3 } & Forward:5'- GCCAAGAGA TGC TGT TGATG-3' \\
\hline & Reverse: 5'-AGGTCTGTGAAGGCGTTGTA-3' \\
\hline \multirow[t]{2}{*}{ MMP-13 } & Forward: 5'-TTCGGCTTAGAGGTGACAGG-3' \\
\hline & Reverse: 5'-ACTCTTGCCGGTGTAGGTGT-3' \\
\hline \multirow[t]{2}{*}{ PRG4 } & Forward: 5'-GAACGTGCTATAGGACCTTC - 3' \\
\hline & Reverse:5'-CAGACTTTGGATAAGGTCTGCC - 3' \\
\hline \multirow[t]{2}{*}{ UPA } & Forward :5'-CCAGACCACCAGAGAAGACC-3' \\
\hline & Reverse:5'-TGATGAGCCAGTGTGTCAGC-3' \\
\hline \multirow[t]{2}{*}{ TIMP-1 } & Forward: 5'-GCAACTCCGACCTTGTCATC-3' \\
\hline & Reverse: 5'-AGCGTAGGTCTTGGTGAAGC-3' \\
\hline \multirow[t]{2}{*}{ TIMP-3 } & Forward: 5'-TCTGCAACTCCGACATCGTG-3' \\
\hline & Reverse: 5'-CGGATGCAGGCGTAGTGTT-3' \\
\hline \multirow[t]{2}{*}{ a-SMA } & Forward:5'-TGCTGTCC CTCTATGCCTCT-3' \\
\hline & Reverse:5'-GAAGGAATAGCCACGCTCAG-3' \\
\hline
\end{tabular}




\section{Statistical analysis}

Statistical treatment was performed using Graphpad Prism 8.0 software. The all data in this study were expressed as mean \pm standard deviation. One-factor analysis of variance(one-way ANOVA) was used to analyze the gene and protein levels. The ACL-injured cohort at each time point was compared with the normal ACL control, while the MCL-injured cohort at each time point was compared with the normal MCL control. Statistical significance was established at $\mathrm{P}<0.05$.

\section{Results}

\section{Histological differences after injury}

The tissue changes at different time points after the injury of ACL and MCL were observed by HE staining, and it was found that ACL and MCL did not change significantly at each time point at the injury (Fig. 1B1F and Fig. 1a-1f).

Notes: A-E indicates ACL; a-e indicates MCL. A-Normal ACL, a-Normal MCL; B1-ACL injury 3d, b1-MCL injury 3d; C1-ACL injury 1w, c1-MCL injury 1w; D1-ACL injury 2w, d1-MCL injury 2w; E1- ACL injury 4w, e1MCL injury $4 w$; F1-ACL injury $6 w$, f1-MCL injury $6 w . B 2-F 2$, b2-f2 is a partial enlargement.

\section{Expression Differences Of Related Genes}

According to RT-qPCR, it was found that,compared with the control group, the partially injured ACL and MCL had significant differences in the expression of many related genes, and two ligaments had significant differences in genes expression at different time points after their injury.

\subsection{MRNA Expression Of Collagen}

In ACL, compared with the normal group, the expression of COL-I mRNA in the injured group was fluctuating, which was statistically significant at 4 weeks $(P<0.05)$ (Fig. 2a). While the expression of type III collagen mRNA was injured After 3 days, it increased to 4 weeks and then decreased (Fig. 2b).On the contrary, in MCL, compared with the normal group, the expression of type I and type III collagen mRNA continued to increase at 3 days after injury and reached a peak at 2 weeks. The expression of type III collagen mRNA had significant statistical significance at 2 weeks $(P<0.001)$ (Fig. $2 b)$, and there was also a statistical difference at $4 \mathrm{w}(\mathrm{P}<0.05)$.

(Notes* indicates $\mathrm{P}<0.05$, $* \star \star$ indicates $\mathrm{P}<0.001$ as compared to $\mathrm{ACL}$ control group. ${ }^{+}$indicates $\mathrm{P}<0.05$, ${ }^{+++}$indicates $\mathrm{P}<0.001$ as compared to MCL control group).

\subsection{MRNA Expression Of Matrix Metalloproteinases}

In ACL, compared with the normal group, the expression of the matrix metalloproteinases MMP3, MMP13 and uPA mRNA increased in the injured group at 3 days after injury. The difference was that the mRNA expression of MMP3 and uPA peaked at 1week and then decreased, while the expression of MMP13 
mRNA continued to rise from 1 week. There was a significant difference between the mRNA expression of MMP3 and uPA at 1week $(P<0.001)$ (Fig. 3a), while the expression of MMP13 mRNA was statistically significant at 6 weeks $(P<0.05)(F i g .3 b)$. On the contrary, in $M C L$, there was a significant difference with Compared with the control group in the injury group, and the mRNA expression of MMP13 and uPA did not change (Fig. 3b, 3c). However,the expression of MMP3 mRNA increased at 1week, which was statistically significant $(P<0.001)$ (Fig. 3a).

(Notes * means indicates $\mathrm{P}<0.05$, *** indicates $\mathrm{P}<0.001$ as compared to $\mathrm{ACL}$ control group. ${ }^{+}$indicates $\mathrm{P}<0.05,{ }^{+++}$indicates $\mathrm{P}<0.001$ as compared to $\mathrm{MCL}$ control group).

\subsection{MRNA Expression Of Matrix Metalloenase Inhibitors}

The mRNA expression of Matrix metalloenase inhibitors were significantly different in injured ACL and MCL. In ACL, compared with 3 days to 4 weeks and was statistically significant $(P<0.001)$ (Fig. $4 a)$. But the mRNA expression of TIMP3 was decreased at 1 week and 2 weeks $(P<0.05)$ (Fig. 4b). While there was no change in MCL compared with the control group (Fig. 4b), and the expression of TIMP3 mRNA increased at 2 weeks and 4 weeks, which was statistically significant $(P<0.05)$ (Fig. 4b).

\subsection{MRNA Expression Of Angiogenesis-related Factors}

According to the following histogram, compared with the control group, in ACL, the expression of TGF- $\beta$ mRNA did not change at all time points (Fig. 5a), while mRNA expression of the NGF increased 3 days after injury, which was statistically significant at 4 weeks $(P<0.001)$ (Fig. 5b). The mRNA expression of VEGF began to decrease from 3days, and it was statistically significant at 3 days and 1 week $(P<0.001)$ (Fig. 5c).On the contrary, the mRNA expression for TGF- $\beta$ was higher than the control group at all time points in MCL. Both have obvious statistical significance $(P<0.001)$ (Fig. 5a). The mRNA expression for NGF increased at 6 weeks of injury $(P<0.05)$ (Fig. $5 b)$, while The expression of VEGF mRNA expression also began to decrease at 3 days, but the decrease was much lower than ACL.

\subsection{Differences In Mrna Expression Of Other Related Factors}

Compared with the control group, the mRNA expression of aSMA in MCL and ACL injuries both increased from $3 d$, and there was significant statistical significance at 3days, 1 week and 2 weeks $(P<0.001)$ (Fig. 6a). The difference was the expression of PRG4 mRNA, the MCL after injury continued to increase $(P<0.001)$ (Fig. 6b), but there was no change in ACL.

\subsection{Changes in the expression of each gene at different time points of injury to ACL and MCL}

According to RT-qPCR, the mRNA expression changes of 12 genes are made into the following table, and it is very intuitive to see the changing trend of different genes at different times of injury. 
Table 2

Compared with the control group, the mRNA expression changes of each gene at different time points in the ACL injury group

\begin{tabular}{|c|c|c|c|c|c|}
\hline Gene & $3 d$ & $1 w$ & $2 w$ & $4 w$ & $6 w$ \\
\hline COL-I & $\downarrow(0.9)$ & - & $\downarrow(0.8)$ & $\uparrow(1.6)$ & $\uparrow(1.5)$ \\
\hline COL-III & - & $\uparrow(3.4)$ & $\uparrow(4.8)$ & $\uparrow(6.8)$ & $\downarrow(0.7)$ \\
\hline MMP3 & $\uparrow(2.9)$ & $\uparrow(8.9)$ & $\uparrow(2.2)$ & $\downarrow(0.5)$ & $\downarrow(0.04)$ \\
\hline MMP13 & $\downarrow(0.5)$ & $\downarrow(0.5)$ & $\downarrow(0.8)$ & $\uparrow(1.5)$ & $\uparrow(1.7)$ \\
\hline TIMP1 & $\uparrow(11)$ & $\uparrow(5)$ & $\uparrow(9.3)$ & $\uparrow(7.7)$ & $\downarrow(0.7)$ \\
\hline TIMP3 & $\downarrow(0.4)$ & $\downarrow(0.3)$ & $\downarrow(0.5)$ & $\downarrow(0.6)$ & - \\
\hline UPA & - & $\uparrow(8.5)$ & - & - & $\downarrow(0.3)$ \\
\hline TGF- $\beta$ & $\downarrow(0.3)$ & $\downarrow(0.8)$ & $\downarrow(0.2)$ & $\downarrow(0.07)$ & - \\
\hline VEGF & $\uparrow(5.2$ & $\uparrow(2.3)$ & $\downarrow(0.8)$ & $\downarrow(0.3)$ & $\downarrow(0.1)$ \\
\hline NGF & - & - & - & $\uparrow(4)$ & $\uparrow(4)$ \\
\hline PRG4 & - & - & - & - & - \\
\hline aSMA & - & - & - & - & - \\
\hline \multicolumn{6}{|c|}{$\begin{array}{l}\text { Notes: }(\uparrow) \text { indicates gene expression increased as compared with ACL controls. Magnitude of change } \\
\text { (fold-change compared to normal control) in parentheses. ( } \downarrow \text { ) indicates gene expression decreased as } \\
\text { compared with ACL controls. Magnitude of change (fold-change compared to normal control) in } \\
\text { parentheses. }\end{array}$} \\
\hline
\end{tabular}


Table 3

Compared with the control group, the mRNA expression changes of each gene at different time points in the MCL injury group

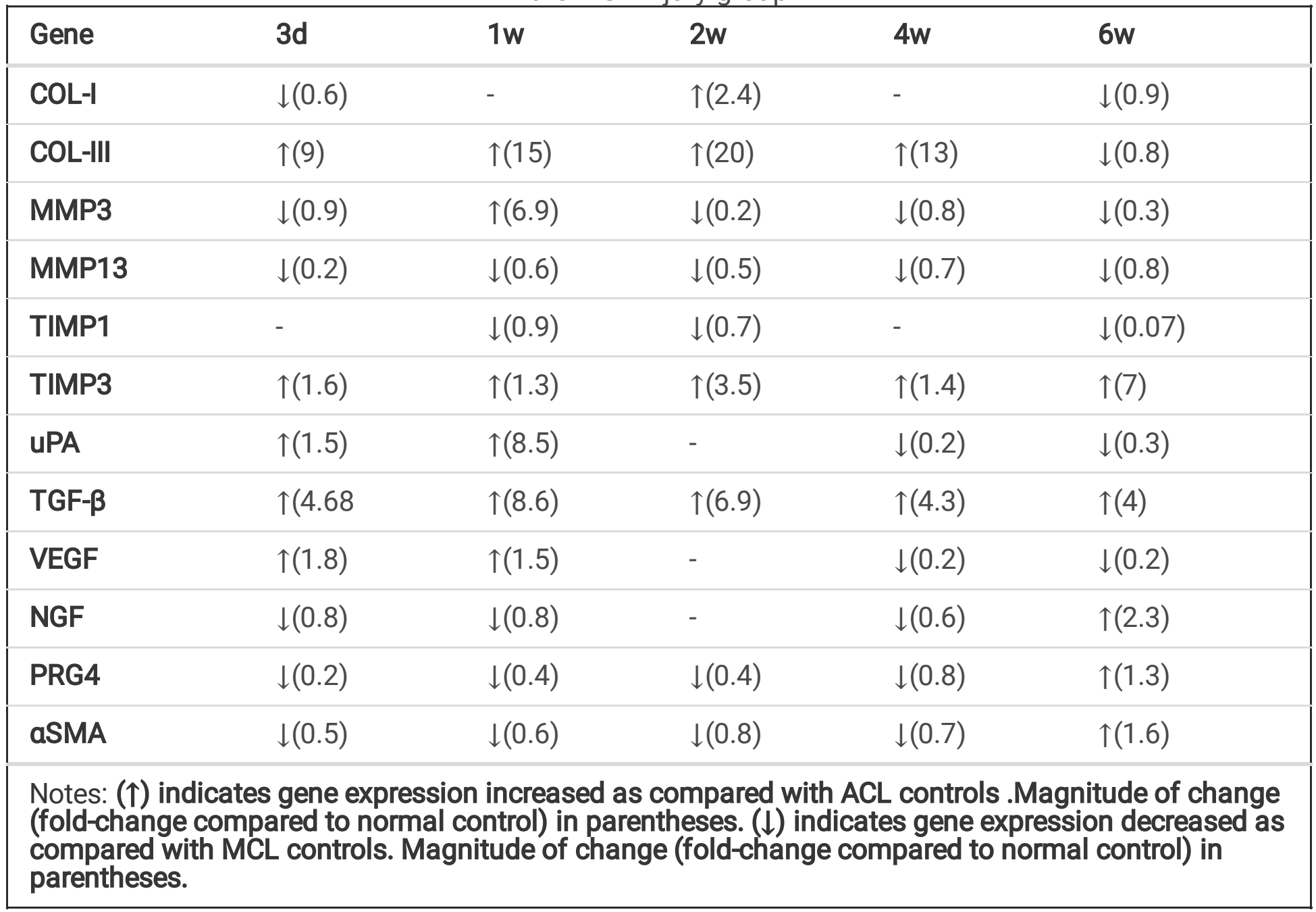

\section{Differences In The Expression Of Related Proteins}

The collagen and matrix metalloproteinases of ligaments were quantitatively analyzed by Western blot. No matter $\mathrm{ACL}$ or $\mathrm{MCL}$, the protein expression of collagen and matrix metalloproteinase decreased. The expression of type I and type III collagen, MMP3 and MMP13 in ACL decreased from 3 days after injury $(P<0.001)$ (Fig. 7), and increased slightly at 4 weeks. While in MCL, type I and type III collagen, MMP3 and MMP13 protein levels continued to decline from 3 days after injury (Fig. 7b-7e), and the expression of these four proteins in MCL was higher than that in ACL.

\section{Discussion}

\section{Animal model}

To further integrate clinical practice and make animal experiments and clinical cases more uniform, we improved the modeling method of the original injury. Without damaging other ligaments, we used a 
syringe gun head to pierce ACL and MCL (as shown in the figure below - see Animal model figure in the Supplementary Files), making the ligament tear mode close to the ligament injury mode of patients, and provide more reference for clinical diagnosis and treatment.

\section{Results}

ACL plays an important role in controlling and stabilizing the knee joints, but it has a poor healing capacity. Molecular differences between the ACL and the MCL help to explain their different healing abilities. However, the process of injury and repair of the ACL and MCL is very complex. Therefore, we need to study the differences in different ways. Previous studies of ACL injury mainly have focused on ACL reconstruction. Here, we study the molecular biological differences at the time of injury.

In this study, we conducted a comparative study of molecules associated with the ACL and MCL at different times after injury. Comparative studies were conducted in terms of the collagen composition of the ligament, matrix metalloproteinases, and their inhibitors, and angiogenesis-related molecules to find the molecular causes of the differences in the healing ability of ACL and MCL injuries. We mainly focused on MMP3 and MMP13. Because they are key players in the various stages healing process, these stages can eliminate damaged proteins, disrupt the temporary ECM, possibly control angiogenesis and regulate the activity of certain growth factors[31].

In the injured $A C L$, the mRNA expression level of MMP3 increased to $1 \mathrm{w}$ for the first time after injury, but the expression of MMP13 continued to increase after injury. The expression of matrix metalloproteinase activator uPA followed the same trend as the expression of MMP3. Differently,in MCL injured tissue, MMP13 mRNA expression was lower compared with the MCL control at multiple time points after injure, in contrast to after ACL. MMP13 tended to decrease after MCL injury, indicating that its ability to degrade extracellular matrix and collagen was weaker than injured ACL $\square$ which facilitated the formation of scar tissue and repair of injured ligaments. The differential expression of matrix metalloproteinases between injured ACL and MCL may be related to the location of the ligaments. The ACL is located within the joint capsule. After the injury, ACL is exposed to a synovial fluid containing inflammatory substances that inhibit healing[32]. Previous studies have also reported a significant increase for MMP13 mRNA expression in cartilage and synovium following ACL injury[33]. Several researchers have also observed a similar sustained upward trend in the gene for MMP13 in injured sheep ACLs[34]. Tang et al. reported increased mRNA expression of MMP13 in ACL during the acute phase of ACL injury[33].

In normal tissues, the stoichiometric ratio of MMP13/TIMP1 is 1:1[35]. However, we found that the ratio of MMP-13/TIMP-1 in the injured ACL fluctuated considerably after injury but stabilized at the MCL, indicating that the stability of MMP-13/TIMP-1 was destabilized after injury, which may be an influential factor in the difficulty of self-healing of the ACL. Therefore, inhibition of MMP13 expression in ligaments is considered to be an important factor in promoting ligament tissue repair.

We also did quantitative analysis of protein expression of MMP3 and MMP13 by Western blot. In our experiments, we found inconsistencies between the mRNA expression and protein expression of MMP3 and MMP13, and we considered that some other non-coding RNAs might be involved in the 
transcriptional regulation of MMP3 and MMP13 proteins. The non-coding regulation of MMP3 and MMP13 protein expression has been studied by others. miR-134 was found to regulate MMP3 expression by Chen[36]. Similarly, Seidl $\mathrm{Cl}$ et al [37] found that miR-675 could regulate MMP13 expression, but it has also been found that miR-411 could also regulate MMP13 expression by expression to regulate tissue repair[38].

Collagen is the most abundant substance in ligaments, so differences in ligament composition can be analyzed by estimating the expression of these collagens. In normal tissues, type I and type III collagen remain in a physiologically stable ratio, however, when ligaments are injured and collagen metabolism is disturbed due to impaired cell proliferation and biosynthesis, the amount of type I collagen decreases, and the amount and ratio of type III collagen increases and decreases. The disruption of collagen metabolism is associated with the mechanical properties of the connective tissue.

Our study found that in the injured ACL and MCL, the mRNA expression of type I and type III collagen were different. In MCL tissues, type I and type III collagen gradually increased from 3 days after injury and peaked at 2 weeks, and the trends of both collagen types were generally consistent. In contrast, in ACL tissue, the mRNA expression of type I collagen fluctuated at different times after ACL injury, whereas the mRNA expression of type III collagen gradually increased after injury, reaching a maximum at 4 weeks, with a different trend from the mRNA expression of these two collagens in MCL.

One investigator found increased collagenase activity and decreased total collagen in the damaged ACL, which is generally consistent with our findings. Similarly, it has been found that collagen mRNA levels of the injured MCL were higher than that of the ACL at all postoperative time intervals. This suggests that collagen mRNA levels are higher in MCL tissue than in ACL tissue in both normal and injured states[39], which is supported by protein blotting studies of collagen expression. In addition, numerous in vitro studies have shown that natural fibroblasts from these tissues have intrinsically different abilities to proliferate, migrate and produce matrix ${ }^{15}$. The ACL and MCL exhibit completely different healing processes following injury. The injured MCL heals easily and forms a visible scars[40], whereas the injured ACL never heals. The amount of scar tissue formed in the ligament after ACL injury is reduced due to the reduced structural protein synthesis potential after injury.

In this study, the gene expression of NGF and VEGF was found to change considerably after an ACL injury but stabilized at the MCL. The gene expression of NGF gradually increased after an ACL injury, indicating an abundant distribution of nerves within the ACL. Our previous study also found that there are more mechanoreceptors to transmit nerve signals in the ACL than in the MCL[41]. TGF- $\beta$ is an important growth factor for fibroblasts and myofibroblasts and is one of the most important promoters of scar formation [42]. In our study, TGF- $\beta$ gene expression was reduced after ACL injury but increased in the injured MCL, which correlated with the healing ability of both.

TGF- $\beta$ can induce angiogenesis by directly stimulating cytokines involved in endothelial growth and by promoting the surrounding environment. TGF- $\beta$ may play an important role in promoting ligament repair 
and remodeling. Gene expression of vascular endothelial growth factor increased and peaked 3 days after ACL injury and then continued to decline with an increased decline; however, in the injured $\mathrm{MCL}$, VEGF expression gradually decreased but increased at 6weeks after injury. Based on the trends in VEGF gene expression in the ACL and MCL before the injury, expression was relatively stable after injury in the $M C L$, suggesting that the MCL is richly vascularised but the ACL is different. The upper third of the injury is the most abundant location in the anterior cruciate ligament and is less vascular, severely compromising blood supply and neovascularization. In a recent study, Bray et al. found that the MCL has a good blood supply, which may be an influential factor in its strong self-healing ability[10].

Besides, we also studied aSMA and PRG4 and found that the mRNA expression of aSMA increased gradually after $A C L$ and $M C L$ injury, but the difference was that the increase was more pronounced in injured MCL and the change in TGF- $\beta$ was more pronounced than in ACL. This suggests that vascular smooth muscle is more active after MCL injury than $A C L$, vascularity is more abundant in $M C L$ fibroblasts. Meanwhile, several studies have found that in both intact and damaged human ACL, myofibroblasts play an important role in the systolic phase of ligament healing, allowing them to regain their original length[43-44].

In ACL and MCL, we found that the expression of PRG4 began to decrease at 3 days after injury. The difference was that the trend of change after injury was less pronounced in ACL, which was lower than the normal group but gradually increased in MCL, exceeding the level of the normal group at 6 weeks after injury, indicating that MCL had more active cell growth factors and also suggesting a more pronounced anti-inflammatory effect after injury in MCL than in ACL. Some animal studies have also found that PRG4 concentrations in ACL begin to decline at three weeks post-injury and only return to normal values within one-year post-injury[45-46].

From our research, we believe that differences in ligament healing ability may be due to several factors. The ACL is an extracellular structure surrounded by a thin layer of synovial tissue in the intra-articular environment and is therefore exposed to synovial fluid, hemorrhagic breakdown products and proteolytic enzymes when synovial tissue is ruptured[47]. Due to its extra-articular location and very limited vascular bed environment, the ACL is unable to form intermediate scar tissue and lacks an initial inflammatory response, resulting in a lack of good self-healing ability.

By studying mRNA for collagen, matrix metalloproteinases and their inhibitors, and angiogenesis-related factors, molecular differences between the ACL and MCL following injury were identified and validated from several specific proteins. We provide a direction and basis for the study of endogenous repair of the ACL, but our experiments still have some limitations. The protein expression studied was not comprehensive enough to were interfered with by other factors in the regulation of protein expression. Identifying these interfering factors may more accurately explain the differences in repair between injured $A C L$ and injured MCL, which is the direction of our subsequent work.

\section{Conclusion}


The results show that there were a significant difference between $A C L$ and $M C L$ in terms of vascular renewal, collagen and matrix metalloproteinases after injury, with $\mathrm{MCL}$ showing lower changes in matrix metalloenzymes and higher vascular renewal than ACL, indicating that MCL is more stable after injury and has a higher self-healing and anti-inflammatory capacity than ACL. The expression of PRG4 and aSMA were both higher in MCL than in ACL, indicating that the former was stronger than the latter in terms of fibroblast viability and cytokine activity after ligament injury. Therefore, it can be found that the repair ability of $A C L$ and $M C L$ after injury is related to the difference in molecular expression.

\section{Declarations}

Funding $\square T$ This study was supported by Natural Science Foundation Guidance Program Project of Liaoning Province『NO. 20180550251.】

\section{Compliance with ethical standards}

Conflicts of interest The authors afrm that they have no confict of interest.

Availability of data and material All data generated or analysed during this study are included in this published article.

Authors' contributions Yinhe Han: Data curation, Writing-Original draft preparation $₫$ Specific experimental operation. Huining Gu: surgery for model. Mingzheng Zhang: surgery for model. Bin Li: Conceptualization,Supervision. Yu Wen『experimental design冈reviewing and editing.

\section{References}

[1] Kaeding CC, Léger-St-Jean B, Magnussen RA (2017) Epidemiology and Diagnosis of Anterior Cruciate Ligament Injuries. Clinics in sports medicine.36(1):1-8. https://doi.org/10.1016/j.csm.2016.08.001

[2] Zhou D, Lee HS, Villarreal F, Teng A, Lu E, Reynolds S, Qin C, Smith J, Sung K L (2005) Differential MMP-2 activity of ligament cells under mechanical stretch injury: an in vitro study on human ACL and MCL fibroblasts, J Orthop Res 23:949-957. https://doi.org/10.1016/j.orthres.2005.01.022

[3] Chen H, Tang Y, Li S, Shen Y, Liu X, Zhong C (2002) Biologic characteristics of fibroblast cells cultured from the knee ligaments, Chin J Traumatol 5(2) 92-96.

[4] Alameddine HS, Morgan JE (2016) Matrix Metalloproteinases and Tissue Inhibitor of Metalloproteinases in Inflammation and Fibrosis of Skeletal Muscles.J Neuromuscul Dis3: 455-473. https://doi.org/10.3233/JND-160183

[5] Frank CB, Jackson DW (1997) The science of reconstruction of the anterior cruciate ligament. J Bone Joint Surg Am79:1556-1576. https://doi.org/10.2106/00004623-199710000-00014 
[6] Bedi A, Kawamura S, Ying L,Rodeo SA (2009) Differences in tendon graft healing between the intraarticular and extra-articular ends of a bone tunnel.HSS J5:51-57. https://doi.org/10.1007/s11420-0089096-1

[7] Cao M, Stefanovic-Racic M, Georgescu H I, Fu FH, Evans CH (2000) Does nitric oxide help explain the differential healing capacity of the anterior cruciate, posterior cruciate, and medial collateral ligaments? Am J Sports Med 28:176-182. https://doi.org/10.1177/03635465000280020701

[8] Kobayashi S, Baba H, Uchida K, Negoro K, Sato M, Miyazaki T, Nomura E, Murakami K, Shimizubata M, Meir A (2006) Microvascular system of anterior cruciate ligament in dogs. J Orthop Res 24:71509-1520. https://doi.org/10.1002/jor.20183

[9] Kobayashi K, Healey RM, Sah RL, Clark JJ, Tu BP, Goomer RS, Akeson W H, Moriya H, Amiel D (2000) Novel method for the quantitative assessment of cell migration: a study on the motility of rabbit anterior cruciate (ACL) and medial collateral ligament (MCL) cells. Tissue engineering6:29-38.

https://doi.org/10.1089/107632700320865

[10] Xie J, Huang W, Jiang J, Zhang Y, Xu Y, Xu C, Yang L, Chen PC, Sung KL (2013) Differential expressions of lysyl oxidase family in ACL and MCL fibroblasts after mechanical injury. Injury44:893900. https://doi.org/10.1016/j.injury.2012.08.046

[11] Bray RC, Leonard CA, Salo PT (2002) Vascular physiology and long-term healing of partial ligament tears. J Orthop Res20:984-989. https://doi.org/10.1016/S0736-0266(02)00012-8

[12] Wiig ME, Amiel D, Ivarsson M, Nagineni CN, Wallace CD, Arfors KE (1991) Type I procollagen gene expression in normal and early healing of the medial collateral and anterior cruciate ligaments in rabbits: an in situ hybridization study. J Orthop Res9:374-382. https://doi.org/10.1002/jor.1100090309

[13] Wang Y, Tang Z, Xue R, Singh GK, Liu W, Lv Y, Yang L (2012) Differential response to CoCl2stimulated hypoxia on HIF-1a, VEGF, and MMP-2 expression in ligament cells. Molecular andcellular biochemistry360:235-242. https://doi.org/10.1007/s11010-011-1061-5

[14] Kiapour AM, Murray MM (2014) Basic science of anterior cruciate ligament injury and repair, Bone Joint Res 3: 20-31. https://doi.org/10.1302/2046-3758.32.2000241

[15] Zhang J, Pan T, Im HJ, Fu FH, Wang JH (2011) Differential properties of human ACL and MCL stem cells may be responsible for their differential healing capacity.BMC Med9:68. https://doi.org/10.1186/1741-7015-9-68

[16] Pascher A, Steinert AF, Palmer GD, Betz O, Gouze JN, Gouze E, Pilapil C, Ghivizzani SC, Evans CH, Murray MM (2004) Enhanced repair of the anterior cruciate ligament by in situ gene transfer: evaluation in an in vitro model. Mol Ther10:327-336. https://doi.org/10.1016/j.ymthe.2004.03.012 
[17] Tashiro T, Hiraoka H, Ikeda Y, Ohnuki T, Suzuki R, Ochi T, Nakamura K, Fukui N (2006) Effect of GDF-5 on ligament healing. J Orthop Res 24: 71-79. https://doi.org/10.1002/jor.20002

[18] Senesi L, Farinelli L, Manzotti S, Fravisini M, Gigante A (2018) Nerve growth factor administration on cultured human ligamentocytes: an in vitro pilot study. J Biol Regul Homeost Agents32: 1-7.

[19] Hinz B (2007) Formation and function of the myofibroblast during tissue repair. J Invest Dermatol 127:526-537. https://doi.org/10.1038/sj.jid.5700613

[20] Sun Y, Berger EJ, Zhao C, An KN, Amadio PC, Jay G (2006) Mapping lubricin in canine musculoskeletal tissues.Connect Tissue Res47:215-221. https://doi.org/10.1080/03008200600846754

[21] Cui N, Hu M, Khalil RA (2017). Biochemical and Biological Attributes of Matrix Metalloproteinases. Prog Mol Biol Transl Sci147:1-73. https://doi.org/10.1016/bs.pmbts.2017.02.005

[22] Blázquez-Prieto J, López-Alonso I, Amado-Rodríguez L, Huidobro C, González-López A, Kuebler, WM, Albaiceta GM (2018) Impaired lung repair during neutropenia can be reverted by matrix metalloproteinase-9. Thorax 73:321-330.https://doi.org/10.1136/thoraxjnl-2017-210105

[23] Juan TK, Liu KC, Kuo CL, Yang MD, Chu YL, Yang JL, Wu PP, Huang Y P, Lai KC, Chung J G (2018) Tetrandrine suppresses adhesion, migration and invasion of human colon cancer SW620 cells via inhibition of nuclear factor-kB, matrix metalloproteinase-2 and matrix metalloproteinase-9 signaling pathways. Oncology letters15:7716-7724. https://doi.org/10.3892/ol.2018.8286

[24] Raza SL, Cornelius LA (2000) Matrix metalloproteinases and their native or pharmacologic inhibitors. Adv Dermatol16:185-209.

[25] Leonardi A, Brun P, Sartori MT, Cortivo R, Dedominicis C, Saggiorato G, Abatangelo G, Secchi AG (2005) Urokinase plasminogen activator, uPa receptor, and its inhibitor in vernal

keratoconjunctivitis. Invest Ophthalmol Vis Sci 46: 1364-1370. https://doi.org/10.1167/iovs.04-1196.

[26] Alameddine, HS., Morgan JE., (2016) Matrix Metalloproteinases and Tissue Inhibitor of Metalloproteinases in Inflammation and Fibrosis of Skeletal Muscles, Journal of neuromuscular diseases 3:455-473,https://doi.org/10.3233/JND-160183.

[27] Georgiev GP, Kotov G, Iliev A, Slavchev S, Ovtscharoff W, Landzhov B (2019) A comparative study of the epiligament of the medial collateral and the anterior cruciate ligament in the human knee. Immunohistochemical analysis of collagen type I and V and procollagen type III, Ann Anat 224:88-96. https://doi.org/10.1016/j.aanat.2019.04.002

[28] Chamberlain CS, Crowley EM, Kobayashi H, Eliceiri KW, Vanderby R (2011) Quantification of collagen organization and extracellular matrix factors within the healing ligament. Microsc Microanal17:779-787. https://doi.org/10.1017/S1431927611011925 
[29] Chun J, Tuan TL, Han B, Vangsness CT, Nimni ME (2003) Cultures of ligament fibroblasts in fibrin matrix gel. Connect Tissue Res44:81-87.

[30] Murakami H, Shinomiya N, Kikuchi T, Fujikawa K, Nemoto K (2005) Differential sensitivity to NOinduced apoptosis between anterior cruciate and medial collateral ligament cells. J Orthop Sci10: 84-90. https://doi.org/10.1007/s00776-004-0858-4

[31] Patterson BC, Sang QA (1997) Angiostatin-converting enzyme activities of human matrilysin (MMP7) and gelatinase B/type IV collagenase (MMP-9). J Biol Chem 272:28823-28825. https://doi.org/10.1074/jbc.272.46.28823

[32] López-Cuenca A, Marín F, Roldán V, Climent VE, Valdés M., Lip GY (2010) Effects of atorvastatin 80 mg daily on indices of matrix remodelling in 'high-risk' patients with ischemic heart disease. Int $\mathrm{J}$ Cardiol 139:95-97. https://doi.org/10.1016/j.ijcard.2008.06.076

[33] Tang Z, Yang L, Zhang J, Xue R, Wang Y, Chen PC, Sung KL (2009) Coordinated expression of MMPs and TIMPs in rat knee intra-articular tissues after ACL injury. Connect Tissue Res50:315-322.

[34] Lo IK, Marchuk L, Majima T, Frank CB, Hart DA (2003) Medial collateral ligament and partial anterior cruciate ligament transection: mRNA changes in uninjured ligaments of the sheep knee. $\mathrm{J}$ Orthop Sci8:707-713. https://doi.org/10.1007/s00776-003-0695-x

[35] Gaire M, Magbanua Z, McDonnell S, McNeil L, Lovett DH, Matrisian LM (1994). Structure and expression of the human gene for the matrix metalloproteinase matrilysin. J Biol Chem269:2032-2040.

[36] Chen CL, Zhang L, Jiao YR, Zhou Y, Ge QF, Li PC, Sun XJ, Lv Z (2019) miR-134 inhibits osteosarcoma cell invasion and metastasis through targeting MMP1 and MMP3 in vitro and in vivo. FEBS Lett 593:1089-1101. https://doi.org/10.1002/1873-3468.13387

[37] Seidl Cl, Murphy CL (2019). Dual and Opposing Regulation of MMP1 and MMP13 by Both Arms of miR-675 in Human Articular Chondrocytes. Cell Physiol Biochem53: 172-185.

https://doi.org/10.33594/000000128

[38] Wang G, Zhang Y, Zhao X, Meng C, Ma L, Kong, Y. (2015) MicroRNA-411 inhibited matrix metalloproteinase 13 expression in human chondrocytes. American journal of translational research, 7 : 2000-2006

[39] AbiEzzi SS, Foulk RA, Harwood FL, Akeson WH, Amiel D (1997) Decrease in fibronectin occurs coincident with the increased expression of its integrin receptor alpha5beta1 in stress-deprived ligaments. lowa Orthop J17:102-109.

[40] Frank C, Woo SL, Amiel D, Harwood F, Gomez M, Akeson W (1983) Medial collateral ligament healing. A multidisciplinary assessment in rabbits. Am J Sports Med11:379-389.

https://doi.org/10.1177/036354658301100602

Page 18/25 
[41] Han YH, Li B, Wen Y (2020) Distribution, quantity and gene expression of mechanoreceptors in ligaments and tendons of knee joint in rabbits. J Mol Histol51:233-240. https://doi.org/10.1007/s10735020-09875-8

[42] Gewin $L(2019)$ The many talents of transforming growth factor- $\beta$ in the kidney, Current opinion in nephrology and hypertension. 28(3) 203-210,https://doi.org/10.1097/MNH.0000000000000490.

[43] Murray MM, Martin SD, Martin TL, Spector M (2000) Histological changes in the human anterior cruciate ligament after rupture. J Bone Joint Surg Am 82:1387-1397. https://doi.org/10.2106/00004623200010000-00004

[44] Weiler A, Unterhauser FN, Bail HJ, Hüning M, Haas NP (2002) Alpha-smooth muscle actin is expressed by fibroblastic cells of the ovine anterior cruciate ligament and its free tendon graft during remodeling. J Orthop Res 20:310-317. https://doi.org/10.1016/S0736-0266(01)00109-7

[45] Elsaid KA, Fleming BC, Oksendahl HL, Machan JT, Fadale PD, Hulstyn MJ, Shalvoy R, Jay GD (2008) Decreased lubricin concentrations and markers of joint inflammation in the synovial fluid of patients with anterior cruciate ligament injury. Arthritis Rheum 58: 1707-1715. https://doi.org/10.1002/art.23495

[46] Elsaid KA, Jay GD, Warman ML, Rhee DK, Chichester CO (2005) Association of articular cartilage degradation and loss of boundary-lubricating ability of synovial fluid following injury and inflammatory arthritis. Arthritis Rheum 52:1746-1755. https://doi.org/10.1002/art.21038

[47] Barlow Y, Willoughby J (1992) Pathophysiology of soft tissue repair. Br Med Bull48:698-711. https://doi.org/10.1093/oxfordjournals.bmb.a072572

\section{Figures}


$\mathrm{ACL}$

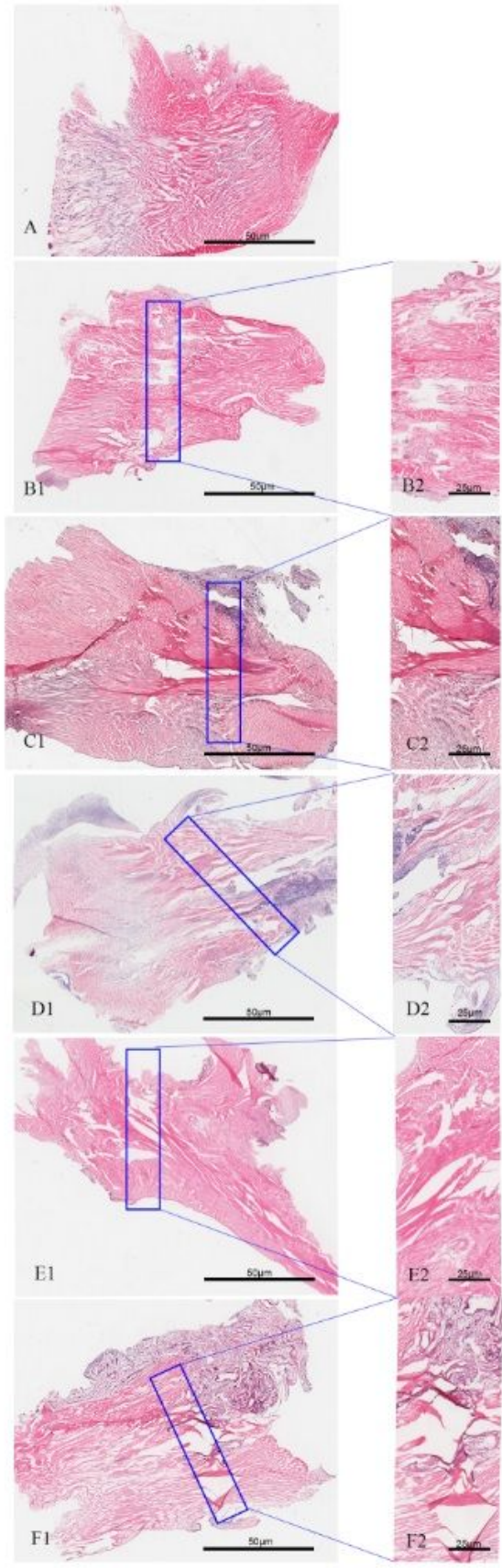

$\mathrm{MCL}$
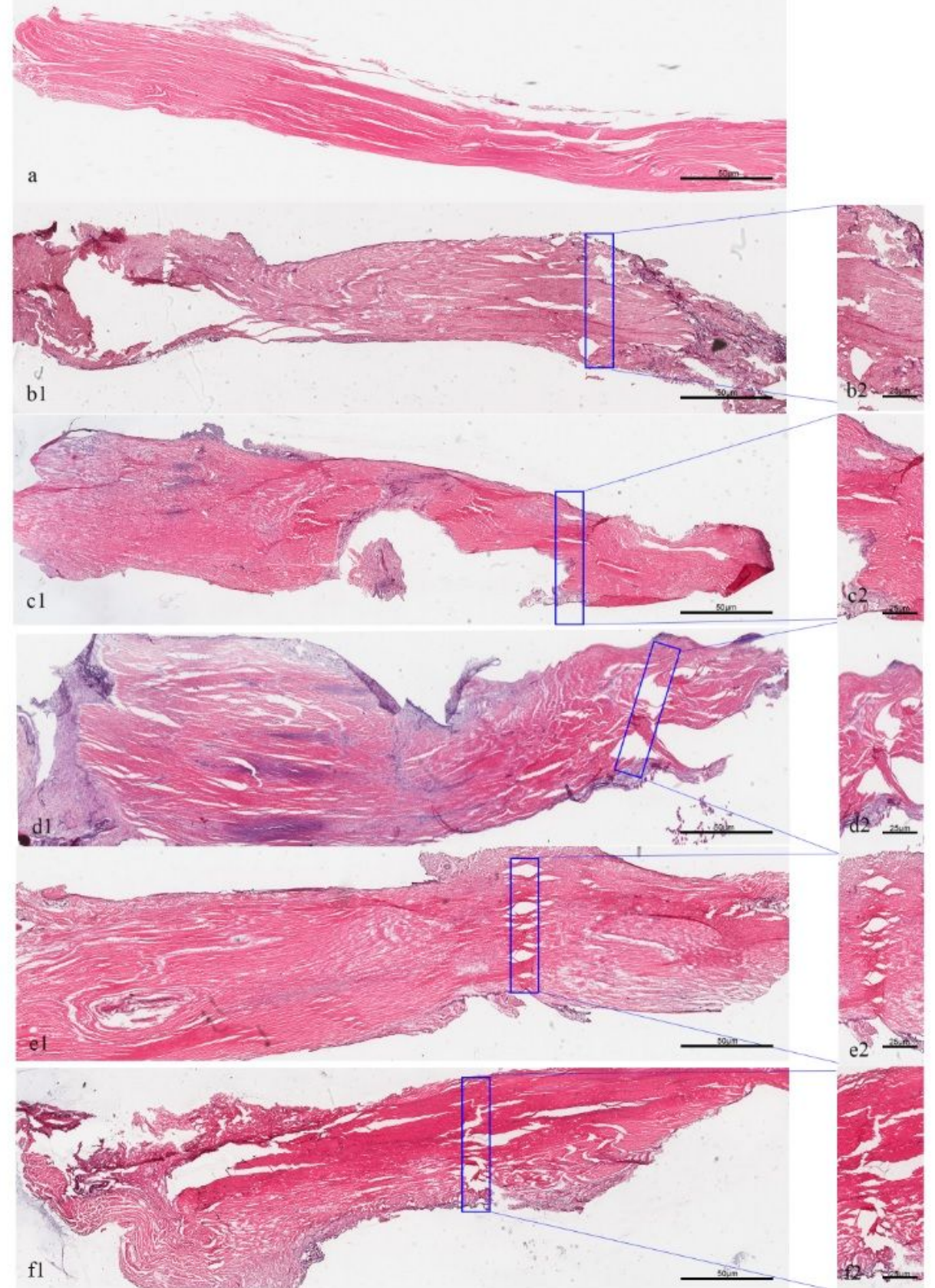

\section{Figure 1}

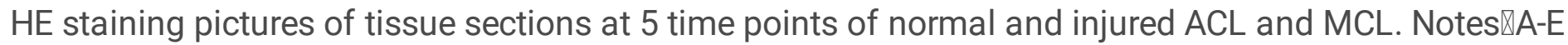
indicates ACL; a-e indicates MCL. A-Normal ACL, a-Normal MCL; B1-ACL injury 3d, b1-MCL injury 3d; C1$A C L$ injury $1 w, c 1-M C L$ injury $1 w$; D1-ACL injury 2w, d1-MCL injury 2w; E1- ACL injury 4w, e1-MCL injury $4 \mathrm{w}$; $F 1-A C L$ injury $6 \mathrm{w}, \mathrm{f1}-\mathrm{MCL}$ injury $6 \mathrm{w} . \mathrm{B} 2-\mathrm{F} 2, \mathrm{~b} 2-\mathrm{f} 2$ is a partial enlargement. 

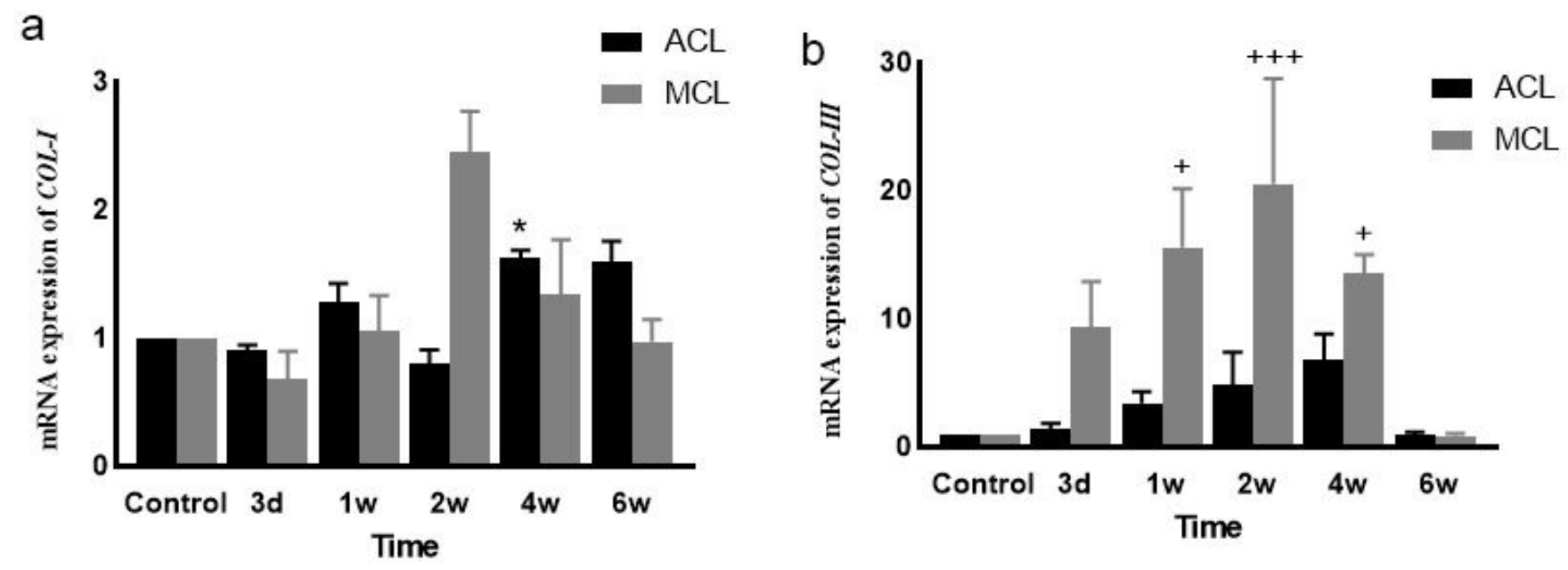

Figure 2

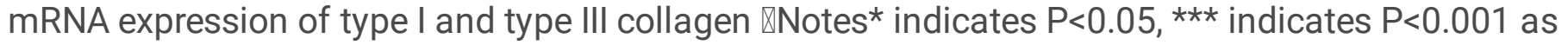
compared to $\mathrm{ACL}$ control group. + indicates $\mathrm{P}<0.05,+++$ indicates $\mathrm{P}<0.001$ as compared to $\mathrm{MCL}$ control group). 

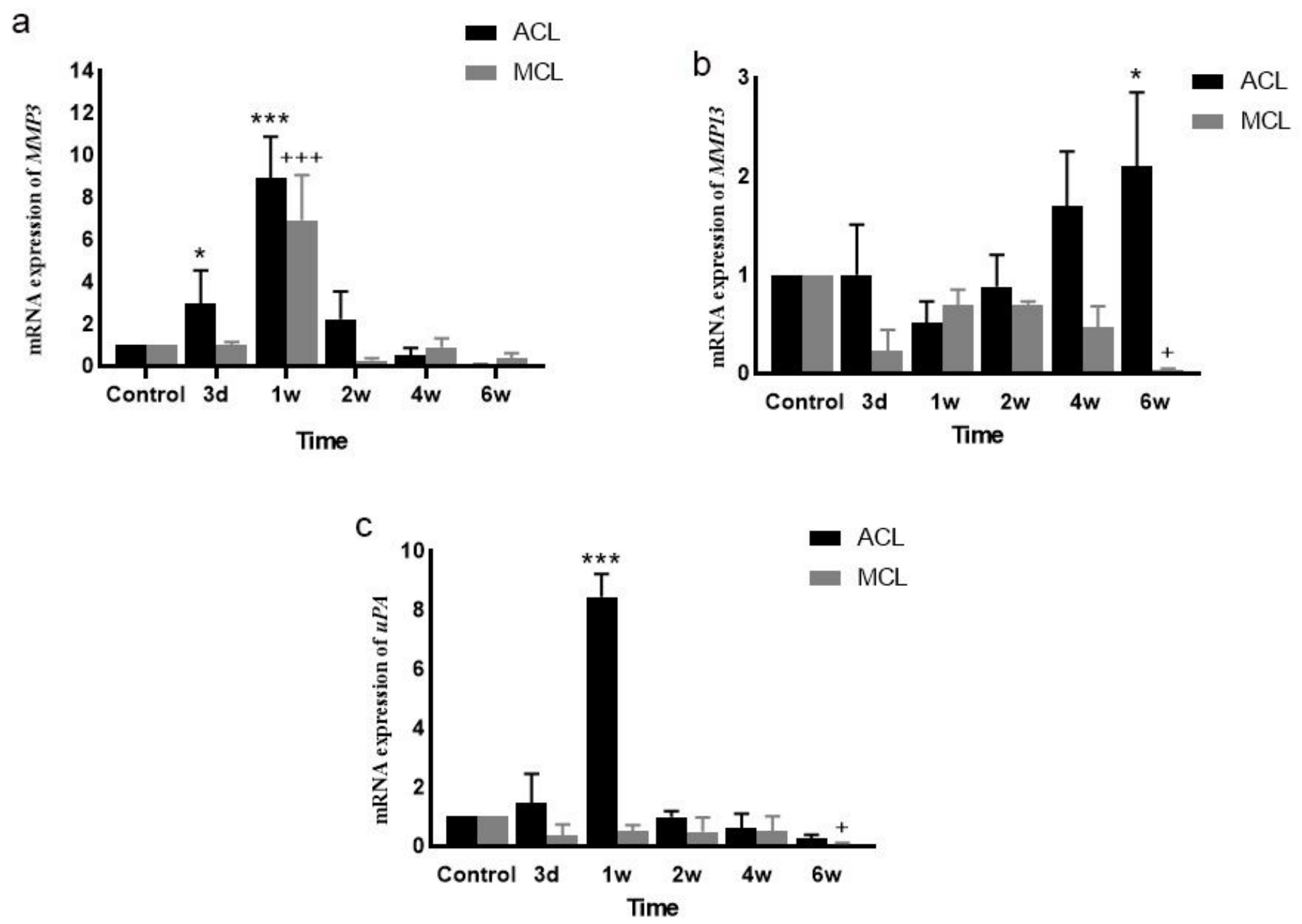

Figure 3

mRNA expression of MMP3, MMP13 and uPA $\triangle$ Notes * means indicates $P<0.05$, $\star \star \star$ indicates $P<0.001$ as compared to $\mathrm{ACL}$ control group. + indicates $\mathrm{P}<0.05$, +++ indicates $\mathrm{P}<0.001$ as compared to $\mathrm{MCL}$ control group).
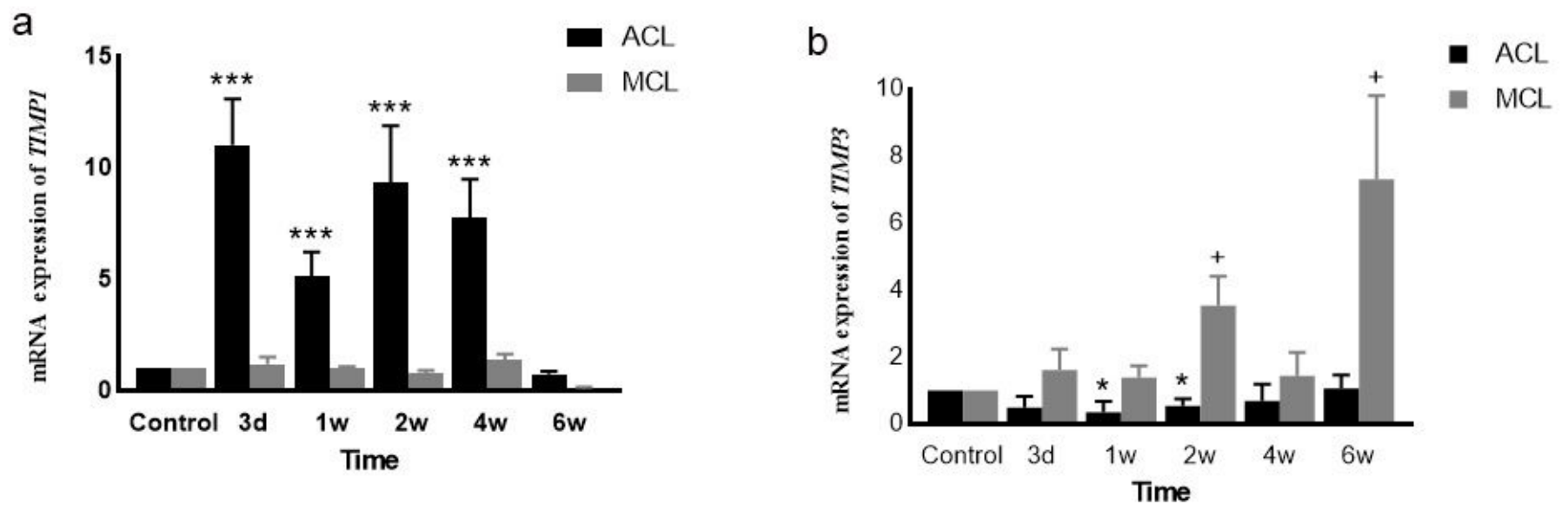
Figure 4

mRNA expression of TIMP1 and TIMP3囚Notes * indicates $\mathrm{P}<0.05$, $* \star *$ indicates $\mathrm{P}<0.001$ as compared to ACL control group. + indicates $\mathrm{P}<0.05,+++$ indicates $\mathrm{P}<0.001$ as compared to $\mathrm{MCL}$ control group).
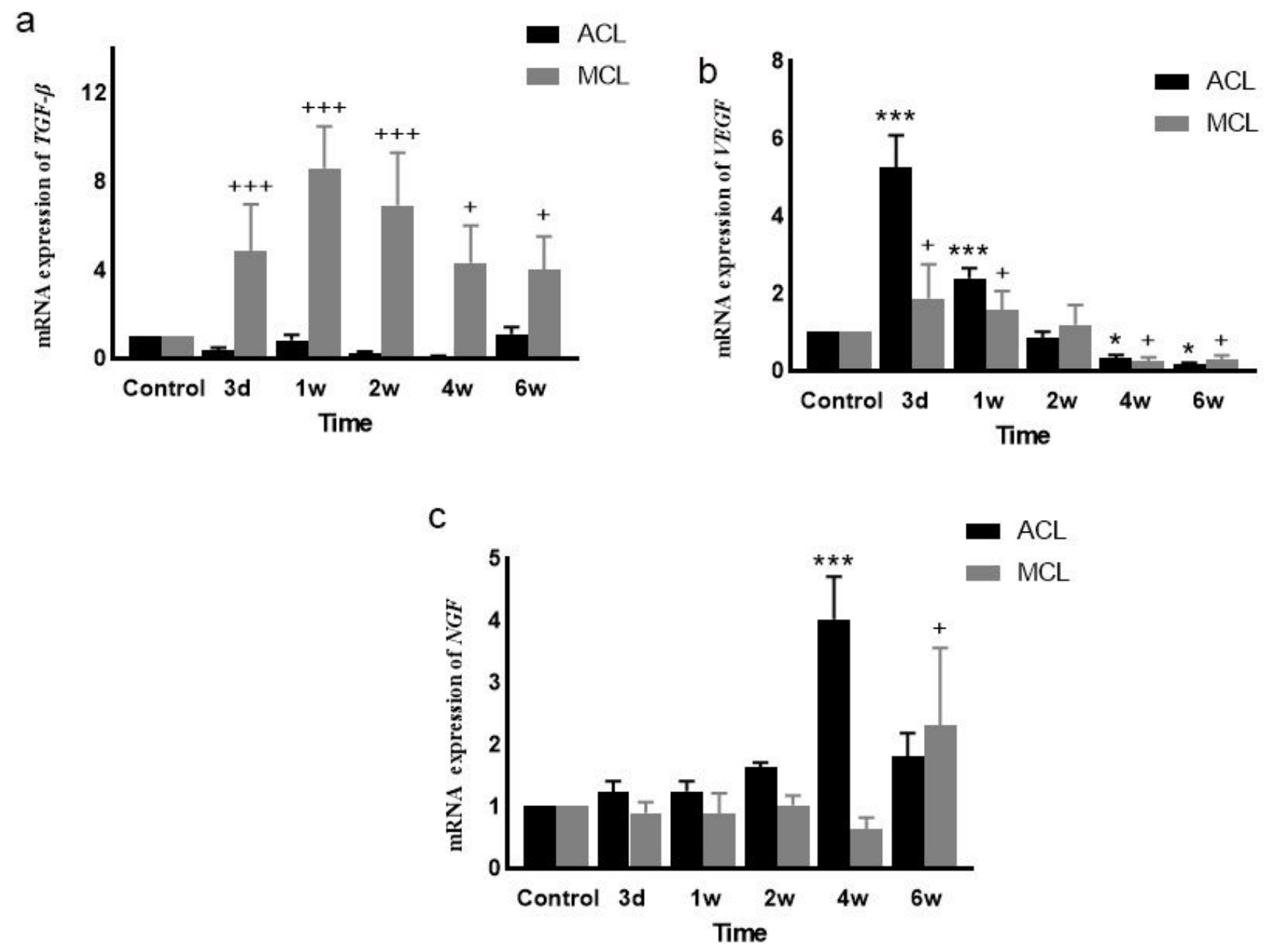

Figure 5

mRNA expression of TGF- $\beta$, NGF and VEGF『Notes * indicates $\mathrm{P}<0.05$, $\star \star \star$ indicates $\mathrm{P}<0.001$ as compared to $\mathrm{ACL}$ control group. + indicates $\mathrm{P}<0.05$, +++ indicates $\mathrm{P}<0.001$ as compared to $\mathrm{MCL}$ control group). 

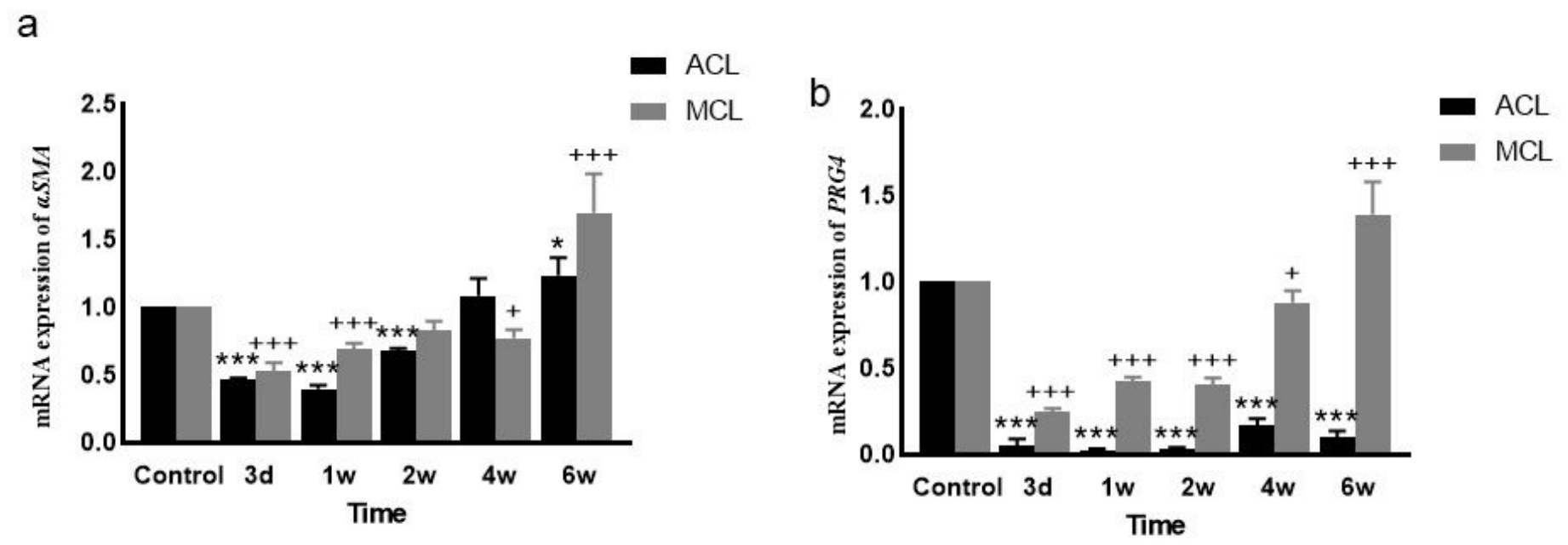

Figure 6

mRNA expression of aSMA and PRG4区Notes * indicates $\mathrm{P}<0.05$, *** indicates $\mathrm{P}<0.001$ as compared with ACL control group. + indicates $\mathrm{P}<0.05,+++$ indicates $\mathrm{P}<0.001$ as compared with $\mathrm{MCL}$ control group) 
a

COL-I

COL-III

-

-

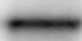

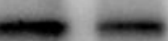

MMP3

MMP 13

$-$

$\longrightarrow$

$\beta$-actin
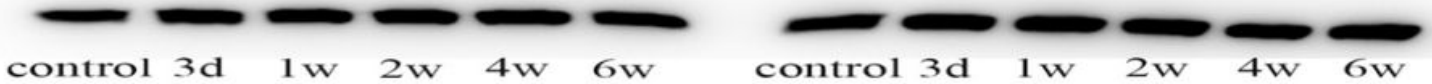

ACL

MCL
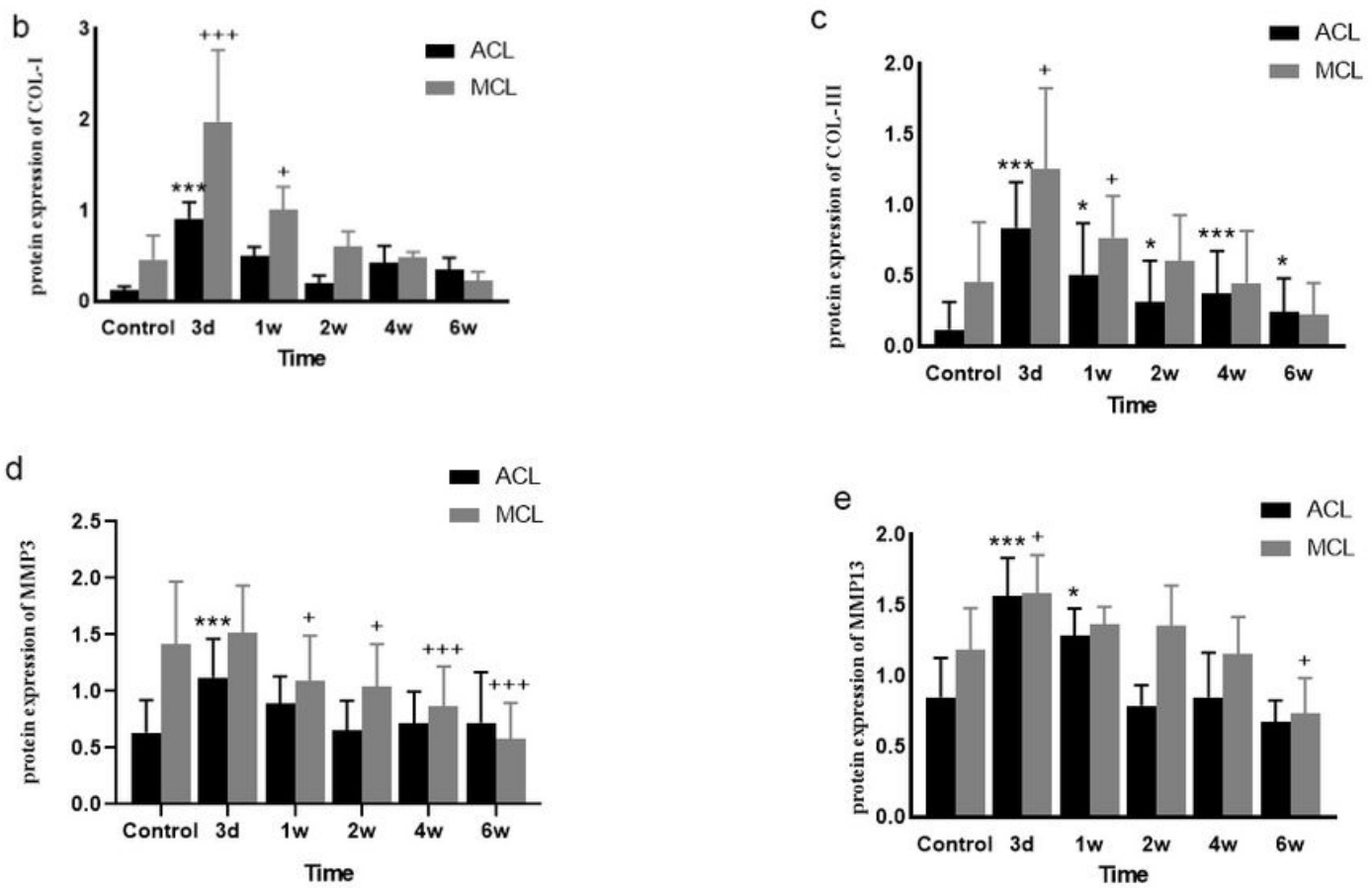

Figure 7

the protein expression of COL-I, COL-III, MMP3 and MMP13 $₫$ Notes * indicates $\mathrm{P}<0.05$, *** $\mathrm{P}<0.001$ as compared with $\mathrm{ACL}$ control group. + indicates $\mathrm{P}<0.05,+++$ indicates $\mathrm{P}<0.001$ as compared with $\mathrm{MCL}$ control group).

\section{Supplementary Files}

This is a list of supplementary files associated with this preprint. Click to download.

- AnimalModelFigure.jpg 